\title{
Profesjonell boksing bør fortsatt være forbudt
}

\author{
Målet i proffboksing er å påføre motstanderen så sterke slag mot hodet at vedkommende faller bevisstløs \\ over ende og ikke greier å reise seg på ti sekunder. I to nyere rapporter er det dokumentert høy risiko for \\ hjerneskader ved proffboksing. Trass i stort medieoppbud rundt en aktuell norsk verdensmester bør vi \\ i Norge opprettholde forbudet mot proffboksing.
}

I de senere år er det publisert en rekke artikler om alvorlige akutte og kroniske skader assosiert med profesjonell boksing. British Medical Association utga i 2008 en grundig utredning med 28 referanser (1). Her dokumenteres høy forekomst av alvorlige hjerneskader, blant annet akutt økt hjernetrykk og hjerneblødninger, langvarige utfall på nevrofysiologiske og nevropsykologiske tester og permanente skader som Alzheimers sykdom, annen demens og parkinsonisme. Siden 1990 er det rapportert 140 dødsfall i forbindelse med boksing. I 2010 ble en omfattende tysk metastudie av det siste tiårs bokseskader publisert (2).

En overveldende datamengde viser at særlig proffboksing er assosiert med omfattende, alvorlige skader, og at risikoen øker med lengden av karrieren, antall nedslaginger og antall tapte kamper. Hodeslagenes dynamikk blir forklart, og ut fra faglige kriterier settes det likhetstegn mellom

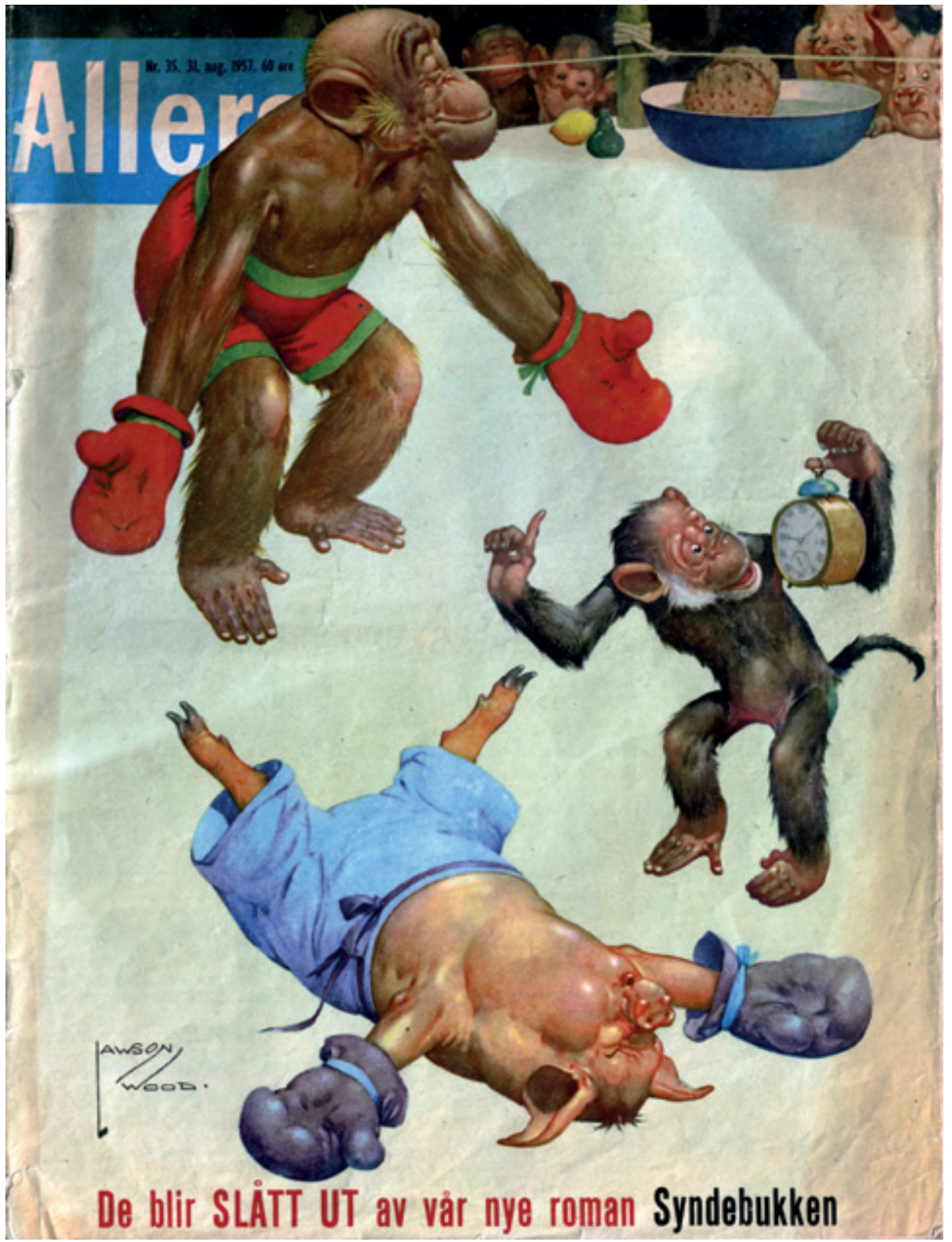

Faksimile fra Allers 1957 knockout og hjernerystelse. 10-20\% av profesjonelle boksere har nevropsykiatriske senfølger. Det anføres også at risikoen for hjerneskade er større ved profesjonell boksing enn ved amatørboksing. I et svensk arbeid fra 1990 som omfattet 47 tidligere amatørboksere ble det ikke påvist varige nevropsykologiske utfall (3), men i en senere svensk studie av 14 amatørboksere ble det påvist langvarig økte celleskademarkører i spinalvæsken etter en boksekamp (4).

I amatørboksing er det innført reglementer og utstyr som skal minske risikoen for skader, men i proffboksing kjemper man fremdeles uten hodebeskyttelse. Proffboksing er heller ikke underlagt dopingkontroll. Profesjonell boksing er likevel tillatt i de aller fleste land. I Sverige var det forbudt fra 1970 til 2006, men er nå tillatt under stramme betingelser og bare etter godkjenning kamp for kamp. I Norge har proffboksing vært forbudt siden 1981.

\section{Hjemlige perspektiver}

I 1998 foreslo to stortingsrepresentanter fra Fremskrittspartiet at forbudet mot profesjonell boksing fra 1981 skulle oppheves. Etter innhenting av faglige råd og gjennomgang av en komitéinnstilling (5) opprettholdt Stortinget forbudet. Her i Tidsskriftet hadde den gang nevrokirurgen Knut Wester er poengtert innlegg mot boksing (6).

I november 2010 fremmet stortingsrepresentanter fra Fremskrittspartiet igjen et forslag om å legalisere proffboksing.

En del av bakteppet var at man for tiden har en norsk verdensmester i boksing. Cecilia Brækhus er veltrent, tøff og blid. Det er ikke rart at mediene svermer rundt henne, noe både hennes tyske managerfirma Sauerland og hun selv er avhengig av - uten mediedekning, ingen pengemaskin. I en av hjembyen Bergens aviser utnevnes hun også til en som slår knockout på tradisjonelle kjønnsroller. Denne dreiingen av fokus vanskeliggjør nøktern, kjønnsuavhengig kritikk av proffboksing. Isolerer man innsatsen til intens trening, konkurranseevne og status som medieidol, er det forståelig at hun under idrettsgallaen i Hamar nylig fikk tittelen Årets navn i åpen klasse. Flytter man derimot perspektivet til det hun og hennes kolleger de facto foretar seg ved å seire på knockout, blir de verdensmestre ved å påføre sine tapende motparter hjernerystelse.

Understøttet av medieinteressen arbeider krefter innenfor både Fremskrittspartiet og 
Høyre for at profesjonell boksing igjen skal bli tillatt i Norge. Argumentene er at forbudet er frihetsberøvende, at deltakelse er frivillig, at boksing var farligere før og at det er lege til stede ved kampene. Boksing krever disiplin og trening, og gode boksere kan være positive forbilder for ungdom i drift. Når nesten alle andre land tillater proffboksing, bør vi i Norge følge med. Endelig påpekes det at det er flere skader i andre større sportsgrener.

Mot dette anføres at det mest relevante ikke er det totale antallet skader, videre at særlig proffboksingen forråer samfunnet og legitimerer latent voldsbruk. Det spesielle ved boksing er også selve hensikten - det å skade motstanderen - mens man i annen sport gjør alt man kan for å hindre skade og straffer både uaktsom og overlagt skade. Motviljen mot hodebeskyttelse skyldes ene og alene frykten for å miste publikumsappell og derigjennom profitt. Med kaldt overlegg utsettes bokserne for økt risiko.

Medienes manglende vilje til å vie helseskadene ved boksing like stor oppmerksomhet som spenningen og glamouren er for påfallende til å forbli upåtalt. Derfor bør Legeforeningen gjøre felles sak med World Medical Association, som uttaler følgende: «Boxing is a dangerous sport. Unlike most other sports its basic intent is to produce bodily harm in the opponent. Boxing can result in death and produces an alarming incidence of chronic brain injury. For this reason, the World Medical Association recommends that boxing be banned» (7).

\section{Vidar Lehmann}

v-lehma@online.no

Søreidtræet 22

5251 Bergen

\section{Oppgitte interessekonflikter: Ingen}

\section{Litteratur}

1. British medical association. Boxing www.bma.org.uk/health_promotion_ethics/ sports_exercise/boxing.jsp (8.2.2011).

2. Förstl $\mathrm{H}$, Haass $\mathrm{C}$, Hemmer $\mathrm{B}$ et al. Boxing-acute complications and late sequelae: from concussion to dementia. Dtsch Arztebl Int 2010; 107: 835-9.

3. Haglund Y, Edman G, Murelius $O$ et al. Does Swedish amateur boxing lead to chronic brain damage? 1. A retrospective medical, neurological and personality trait study. Acta Neurol Scand 1990; 82: 245-52.

4. Zetterberg H, Hietala MA, Jonsson M et al. Neurochemical aftermath of amateur boxing. Arch Neurol 2006; 63: 1277-80

5. Innstilling fra familie-, kultur- og administrasjons komiteen om forslag fra stortingsrepresentantene Jan Simonsen og Per Sandberg om lov om opphevelse av lov av 12. juni $1981 \mathrm{nr} .68$ om forbud mot profesjonell boksing. Innst. 0. nr. 67 (1997-1998). www.stortinget.no/no/ Saker-og-publikasjoner/Publikasjoner/ Innstillinger/Odelstinget/1997-1998/ Inno-199798-067/ (8.2.2011).

6. Wester K. Boksing: forkastelig - og fascinerende. Tidsskr Nor Lægeforen 2000; 120: 1846.

7. WMA statement on boxing www.wma.net/en/ 30publications/10policies/b6/index.html (8.2.2011) 